\title{
Du Bois and Brazil
}

\section{Reflections on Black Transnationalism and African Diaspora}

\author{
Juliana Góes* \\ Department of Sociology, University of Massachusetts at Amherst, MA, USA \\ ${ }^{*}$ Corresponding author. Email: jgoes@umass.edu
}

\begin{abstract}
In this article, I discuss Black transnational solidarity and liberation in the Americas by analyzing the historical relationship between W. E. B. Du Bois and Brazil from 1900 to 1940. At the beginning of the twentieth century, Du Bois was studying, writing, and publishing about Brazil. He was interested in creating international solidarity and cooperation among Black people. However, Du Bois (as well as other African Americans) promoted the idea that Brazil was a place without racism, a racial paradise. This idea served as a basis for a theory that oppressed Afro-Brazilians-the myth of racial democracy. In this article, I explore Du Bois's relationship with Brazil, highlighting possible reasons why Du Bois engaged with the myth of racial democracy. In addition, I argue that this historical event teaches us that an Afro-diasporic liberation project must seriously consider global and material inequalities among Black people.
\end{abstract}

Keywords: Du Bois; Black Transnationalism; African Diaspora; Brazil; Black Liberation

\section{Introduction}

Since the beginning of European colonialism, Black people have been oppressed worldwide. As a result, efforts to create transnational solidarity were not uncommon. ${ }^{1}$ However, our shared oppression has not created a similar project of liberation or erased our differences. In this article, I examine this issue through a historical example-Du Bois's relationship with Brazil. At the beginning of the twentieth century, he was studying, writing, and publishing about this South American country. Du Bois's early writings about Brazil pictured the country as a racial paradise. His goal was to produce international solidarity and cooperation among Black people. However, the "racial paradise" idea formed the basis for the myth of Brazilian racial democracy-a myth that historically counters the reality of violence against Afro-Brazilians. Why did an eminent liberational thinker like Du Bois get trapped into such a misleading and, in the end, dangerous idea? What does such entrapment imply for Afro-diasporic dialogue and liberation? In this article, I explore these questions by analyzing Du Bois's relationship with Brazil from 1900 to $1940 .^{2}$

In the literature, explanations about why Du Bois engaged with the myth of racial democracy are related to his desire to prove that other racial politics were possible (Hellwig 1990; Nunes 2008). ${ }^{3}$ After the abolition of slavery in Brazil in 1888, Brazilian elites tried to whiten the country through miscegenation. That is, they sought to "dilute" Black blood in white blood until it completely disappeared. As a result, there was no functional segregation 
in the country. This does not mean that racism didn't exist in Brazil, but it was performed differently. The Afro-Brazilian population lived in poverty and faced prejudice when trying to access education, jobs, and housing. Still, it was the absence of segregation that caught Du Bois's attention. Overlooking the daily violence suffered by Afro-Brazilians, he analyzed and represented Brazil as a possible example for the United States-a racial paradise that proved that segregation could be extinguished.

Yet, there was another reason why Du Bois got trapped in such a misleading assumption. After conducting extensive archival research at the W. E. B. Du Bois Papers at the University of Massachusetts at Amherst, analyzing more than 100 archived documents related to Brazil, I argue that Du Bois also represented Brazil as a racial paradise because he aligned himself with Brazilian elites (represented by white Brazilian scholars). ${ }^{4}$ Both he and these elites were interested in defending miscegenation. At that time, in the United States, scientists argued that pure race individuals were superior to mixed-race peoples and that race mixture led to degeneration (Hooker 2017; Munanga 1999). Brazilian elites were fighting against this idea, arguing that miscegenation could whiten the population by eliminating Black blood. Simultaneously, Du Bois was fighting against anti-miscegenation laws in the United States and seeking to prove that pure races did not exist. This accounted for the brief alignment between Du Bois and Brazilian elites.

Additionally, in this article, I explore how global inequalities and imperialism impacted Du Bois's Pan-African agenda concerning Brazil. By asking what we can learn from his experience to strengthen Afro-diasporic solidarity, I discuss the importance of considering the differences among Black people and how global inequalities can facilitate or challenge Black folks' engagement in transnational debates.

The article is divided into five sections. First, I explain the myth of racial democracy. Next, I explore Du Bois's writings about Brazil and how he promoted that myth. Later, I explain Du Bois's relationship with Brazilian elites. Then, I discuss Du Bois's elitist orientation, connecting it to his relationship with Brazilian elites. I conclude by analyzing what Du Bois's relationship with Brazil teaches us about Black transnational solidarity, connecting the historical experience under study to the literature about Afro-diasporic dialogue and liberation.

\section{The Myth of the Racial Democracy}

In Brazil, people are racially defined according to their phenotype, regardless of their ancestry. Thus, people are classified as Black if they have African features, such as black/ brown skin color, and curly/coiled hair (see more in Telles 2014). Of note, Brazil is a majority-Black country. The last Brazilian census, in 2010, has the following racial classifications and results: white (47.51\%); pardo (brown color, $43.42 \%$ ); preto (black color, $7.52 \%$ ); yellow (Asians, $1.1 \%$ ); and Indigenous (0.42\%). The category Negro (Negro/ Black) is composed of those who self-declare as pardos and pretos. Together, they represent $50.94 \%$ of the population, and more recent research suggests this number has increased to $56.2 \%$ in 2019 (IBGE 2020). However, Afro-Brazilians' numeric majority has not been reflected in social, political, and economic power. On the contrary, anti-Blackness permeates Brazilian life.

The country had the largest and longest-lasting slavery system in the Americas (Paschel 2016) and, after its abolition, Black people have continued in subaltern positions. Yet Brazil has been widely defined as a racial democracy by scholars, governments, and international agencies such as UNESCO (Hanchard 1994; Munanga 1999; Schwarcz 1993). Racial democracy refers to "a racial system without any legal or institutional obstacles for racial equality and (...) a racial system without prejudice or discrimination" (Domingues 2005, 
p. 10, author's translation). The term was used to describe Brazil in the 1950s, but the idea's roots can be seen before that, when the country was pictured as a racial paradise.

Gilberto Freyre ([1933] 2003, [1936] 2013) is the Brazilian scholar recognized for creating the basis for this myth. Criticizing biological explanations of racial differences, Freyre wrote two books in the 1930s. He argued that racism was something that needed to be overcome and that Brazil was successfully doing so. According to Freyre, in Brazil, the interactions between Black and white individuals were marked by "zones of confraternization." For him, this confraternization was evidenced mainly by the fact that white settlers had sex with Black enslaved women and, consequently, by miscegenation. ${ }^{5}$ While he recognized that white men were acting in oppressive ways toward Black women, Freyre insisted that "there were cases of pure confraternization between the sadism of the white settler and the masochism of Indigenous and Black women" ([1933] 2003, p. 113, author's translation).

Miscegenation was indeed common during slavery in Brazil. However, given the power dynamics of slavery, sexual relations between masters and enslaved women were rapes and not "zones of confraternization" (or sadomasochistic relations). In fact, many Afro-Brazilian feminists argue that the country is rooted in the rape of Black women (Carneiro 2011; Gonzalez 1984; Souza [1983] 1990). However, Freyre ignores these power dynamics and "pushes his selective miscegenation even further, by connecting it [...] to the rise of social democracy in Brazil" (Hanchard 1994, p. 53). In his theory, the alleged zones of confraternization and the miscegenation they promoted decreased the social distance between Black and white people, resulting in harmony between races and creating an inclusive democratic system-a racial democracy. ${ }^{6}$

As we will see later, Brazilian elites used Freyre's ideas to represent the nation as a land of progress, where "advanced" inhabitants had eliminated "backward prejudices." More specifically, Brazilian elites portrayed themselves as colorblind and merciful people, that were even willing to have sex with "them" (see more in Gonzalez 1984). However, miscegenation did not preclude the division between Black and white people, nor did it reduce racism. Recent data in Brazil shows that Black people are the main target of homicides: $75 \%$ of people murdered are Black (Cerqueira et al., 2020). The violence increases when we focus on the youth: in Brazil, one young Black man between the ages of fifteen and twenty-nine is murdered every twenty-three minutes (Escóssia 2016). Additionally, the violence against Black women in the country increased 54\% from 2003 to 2013 (Waiselfisz 2015). In other data, we see that those who are not killed are often subjected to poverty. While white people represent $70 \%$ of the wealthiest Brazilians, Black people represent $75 \%$ of the poorest ones (IBGE 2019).

Furthermore, the myth of racial democracy was followed by the ideology of whitening, which posited that the only way to become a person, a human being, was by becoming white. The seminal work of Neusa Santos Souza ([1983] 1990) demonstrated that within Brazil's culture, being Black meant being irrational, ugly, dirty, emotional, exotic, a monkey devoid of civility and humanity-someone who should be eliminated. Consequently, everyone was motivated to eliminate any sign of Blackness from their bodies, primarily through miscegenation. She writes: “(...) the citizen was characterized as white, respectable services were labeled as 'white-people-services,' being treated with respect was defined as being treated as white. (...) Black people had to deny their Blackness (...) to become human" ([1983] 1990, p. 21, author's translation). The result of this ideology was the erasure of the subjectivity of Afro-Brazilians. Although many Afro-Brazilians fought against the ideology of whitening, others tried everything to look white-from "whitening" their children through miscegenation to deforming their bodies.

This ideology of whitening resulted in a low level of identification with the term "Black" among Afro-Brazilians. As previously explained, Black people in Brazil self-declared as 
pardos (brown color) and pretos (black color). However, the number of people who use the word preto is very low. Being preto was considered something so wrong that even darkskinned Black people avoided the term and self-declared pardo. After all, who wants to affirm that they are the dirty animal that permeates the Brazilian imagination when we talk about Blackness? Although it is widely known today that Brazil was never a racial democracy and that the ideology of whitening is a form of anti-Black violence, vestiges of this ideology still push Black people with a small amount of white heritage (lighter skin, straighter hair, thinner nose, and mouth) to declare themselves pardos, seeking to deny their Blackness (Carneiro 2011). Thus, the myth of racial democracy had a tremendous impact on the life of Afro-Brazilians.

\section{Du Bois and the Myth of Racial Democracy}

Du Bois promoted the idea that Brazil was a racial paradise, which helped create the myth of racial democracy. He studied Brazil from the beginning of the twentieth century, and the first connection between Du Bois and a Brazilian scholar appears in 1911 at the First Universal Races Congress. The event, held in London, gathered scholars from different parts of the world to discuss race. Du Bois attended this event as did João Batista de Lacerda, the director of the National Museum of Rio de Janeiro. Lacerda (1911) presented the paper The Metis, or Half-breeds, of Brazil, in which he argued that Black and white people were from the same human species but from two different races. To support his arguments, Lacerda claimed that the proof that two subjects were from the same species was the ability of their offspring to procreate and that the metis (mixed-race people) in Brazil were highly fertile. Moreover, he argued, the metis had demonstrated intelligence, good physical proportion, and other characteristics superior to those of Black people. Therefore, for him, miscegenation improved Black people.

Lacerda's work caught Du Bois's attention. ${ }^{7}$ Many scholars viewed miscegenation as dangerous and undesirable - the degeneration of the superior race that leads to the end of civilization. Lacerda, however, argued for miscegenation (although he maintained the racist idea that Black folks are inferior). Consequently, Lacerda's work influenced the first publication written by Du Bois on Brazil-an answer to Roosevelt's opinion on the country.

In 1914, Theodore Roosevelt visited Brazil and published his opinion in a weekly magazine called The Outlook. According to the former president, what separated Brazil and the United States was not the number of mixed-race people. He wrote: "it is an entire mistake to speak as if the population of Brazil were so mixed as to be wholly unlike that of Europe or the United States. It is mixed only in the sense in which the populations of Italy and Spain are mixed [...]" (1914, p. 409). In addition, according to Roosevelt, the Brazilians in high social positions were white. They accepted a few Negroes or mulattoes with demonstrated abilities, but most Black people were in the lower ranks. Thus, the difference between both countries, according to Roosevelt, was their attitudes toward the Negro. In Brazil, they looked forward to the complete erasure of Black individuals through their absorption into the white race (miscegenation). In the United States, Black and white folks believed in the complete separation of the races. Roosevelt argued that, as a result, the people of Brazil would have slightly weaker white blood, but would eventually have eliminated the Negro problem. In the United States, in contrast, Roosevelt argued they believed "in treating each man of whatever color absolutely on his worth as a man, allowing him full opportunity to achieve the success warranted by his ability and integrity, and giving to him the full measure of respect to which that success entitles him" (1914, p. 410).

In the same year, Du Bois (1914) responded to Roosevelt in an article published in The Crisis. In this article, he argued that Roosevelt avoided discussing the Negro population, 
despite having visited Rio de Janeiro (a city with hundreds of thousands of Negroes) and Bahia (the largest Black city in the Americas). Additionally, Du Bois claimed that although Roosevelt stated three facts, he also said two falsehoods. From Du Bois's perspective, the facts were: 1) Brazil was absorbing Black people into the white race; 2) there was no color bar to social ascension; and 3) most Black people were still in the lower social class. The lies were: 1) the United States believed in treating each person, regardless of their color, as a person; and 2) miscegenation led to a slight weakening of the white race. Du Bois pointed out that, in the United States, white people believed that civilization could be maintained only if Negroes were in an inferior place. There was no equality. In addition, he used Lacerda's work to argue that mixed-race people were intelligent and capable, and these characteristics proved that their Black blood had not made them worse than "pure whites." Roosevelt's argument, according to Du Bois, sustained pseudo-scientific lies about white superiority. Du Bois further explained that he was not arguing for intermarriage since he considered it normal to marry within the same race. Instead, he was arguing against the scientific lies about Black inferiority.

In answer to Roosevelt, Du Bois depicted Brazil as a place without a color line. He repeated this argument in 1915 in The Negro. This book is an important contribution to Pan-Africanism and challenged the idea that Black people had no history by analyzing African civilizations and the diaspora. Du Bois dedicated an entire chapter to an analysis of the West Indies and Latin America, within which he discussed Brazil. He analyzed the country from slavery onwards, arguing that the color line was not strict. Besides, although $\mathrm{Du}$ Bois mentioned that there were revolts against slavery, he argued that the "whole emancipation was peaceful, and whites, Negroes, and Indians are today amalgamating into a new race" (1915, p. 98). Thus, according to Du Bois, Brazil was characterized by human equality and solidarity.

Later, Du Bois (1916) extended this idea to all of South America. The editors of The Baltimore Afro-American requested several intellectuals, including Du Bois, to give their opinions about the Pan American Congress. Claiming that the color line almost didn't exist in this region, Du Bois argued the United States could benefit from the example of South America in changing its racial politics.

In addition, Du Bois was following and influencing the literature about Brazil, which portrayed the country as a place without a color bar. In Brazil, during slavery, enslaved people's suicide rates and the number of those who died young were much higher than in the United States (Paschel 2016). Yet, the English literature about Brazilian slavery often portrayed it as less violent than other slavery systems due to the miscegenation that occurred in the country. Zita Nunes, who wrote one of the most complete studies on the transnational promotion of the myth of racial democracy, has shown that books such as "South America: Observations and Impressions by the British historian James Bryce (1914) and Harry Johnston's The Negro in the New World (1910), as well as NAACP Secretary Roy Nash's article in The Crisis, The Origin of Negro Slavery in Brazil and his book The Conquest of Brazil (1926) [...]" (Nunes 2008, p. 89) claimed that slavery in Brazil was based on cordial relations and, because of that, the color line didn't exist in that country.

These books were read and recommended by Du Bois. Indeed, Roy Nash asked Du Bois for information about Afro-Brazilians in 1923, before writing his book. ${ }^{8}$ Du Bois suggested many books about the topic, including James Bryce's South America: Observations and Impressions, Harry Johnston's The Negro in the New World, and the article presented by Lacerda at the First Universal Races Congress. ${ }^{9}$ Du Bois and Nash exchanged many letters about the topic, and Du Bois read and commented on Nash's book before its publication, helping to construct the idea that Brazil was a racial paradise. ${ }^{10}$

Du Bois had received reports about racism in Brazil. In 1927, for example, he received a letter from Mrs. T. Ross Farmer. ${ }^{11}$ She had arrived in Brazil "under the illusion that racial 
discrimination and prejudice did not exist." After three years of living there and studying the question, she had evidence of the opposite. ${ }^{12}$ In the same year, Du Bois received another letter from Owen Johnson, a seaman hired for a Brazilian ship. ${ }^{13}$ He reported abuses from the officers and the crew, as well as racial prejudice in Brazil. Yet, these reports were not enough to change Du Bois's definition of Brazil as a racial paradise.

Why did Du Bois engage with the myth of racial democracy? To explore this question, first, we need to understand the context in which he was writing. Between 1910 and 1930, the South American country was a topic hotly debated in the U.S. Black press (Francisco 2014; Hellwig 1990; Pereira 2013). Many Black scholars, activists, and journalists published articles in newspapers like The Crisis, the Chicago Defender, and the Baltimore Afro-American, in which Brazil was depicted as a place without a color line. Their engagement with Brazil was so intense, Nunes (2008) argues, that African American intellectuals and activists helped to create the myth of racial democracy. She compares the dates of the publications about Brazil in the U.S. Black press and the period in which Gilberto Freyre published his most important book, Casa-Grande e Senzala ([1933] 2003). While Brazil was being defined as a place with no color line in the United States from the 1910s, Freyre published his first book only in 1933. Moreover, Gilberto Freyre was in the United States when he was developing his ideas. At that time, he was studying at Columbia University, advised by Franz Boas.

According to Nunes (2008), African Americans engaged in creating and reproducing Brazil's image as a racial paradise to prove to U.S. society that another solution for the "Negro problem" was possible. While Jim Crow had been established in the United States, there was no legal segregation in Brazil. Therefore, U.S. Black people used Brazil's image to counter the United States' racial system. To demonstrate her argument, Nunes explores Robert Abbott's travel to Brazil. He was the founder of the Chicago Defender and visited Brazil in 1923 with his wife, Helen Abbott. When he got back, he published a series of articles called My Trip through South America. In them, Robert Abbott described Brazil as a place where the Negro could enjoy democracy, and that a homogeneous population emerged due to the strong presence of mixed-race people. In addition, he "informed his readers that as a result of his trip, he was 'more determined than ever to fight to make our country, like Brazil, like the Argentine, lands of true democracy, rather than a country of mock democracy" (Nunes 2008, p. 115).

Nevertheless, Nunes highlights that the Abbotts' experiences in Brazil were not always positive. They were refused lodging at hotels, and Helen Abbott faced discrimination due to the difference between her and her husband's color. Helen Abbott's skin was lighter than her husband's, and her insistence on Blackness disrupted the ideology of whitening. According to Nunes, Helen Abbott confessed to her sister the signs that they were not welcome even when they were accepted into a hotel. They were excluded from the hotel's restaurants and advised to eat in a "Negro place." Nevertheless, Nunes affirms that Robert Abbott's desire to represent Brazil as a democratic place was so intense that he neglected to write about these situations.

It is true that African Americans, including Du Bois, had a genuine need to prove that other racial politics were possible for U.S. society. However, Du Bois had yet an additional motivation for engaging with the myth of racial democracy. There was a brief alignment of interests regarding the benefits of miscegenation among Du Bois and Brazilian elites. According to the hegemonic discourse in the United States, pure races (especially white people) were superior, and race mixture led to degeneration. The mixed-race individual was considered an aberration-a crossbreed whose psychiatric characteristics were disturbed because of the unnatural genetic blend and was, consequently, inferior to pure races (Hooker 2017; Munanga 1999). Brazilian elites were fighting against this perspective in defense of their racial politics (whitening the country through miscegenation). At the same 
time, Du Bois believed it was essential to end the anti-miscegenation laws in order to stop lynching in the United States. Thus, there was a convergence of interests that led to this philosophical alignment.

\section{Du Bois, Brazilian Elites, and Miscegenation}

To understand the alignment between Du Bois and Brazilian elites, it is first necessary to follow the development of two different generations of Brazilian scholars, who were mostly white and connected to Brazilian elites. ${ }^{14}$ The dates of the first cohort are from the 1910s to the 1930s - the same period in which the U.S. Black press was very interested in Brazil. During this period, Brazilian scholars were trying to answer the following question: how can we build a prosperous nation considering the significant presence of Black people among Brazilians? (Alencastro 1985; Consorte 1999; Schwarcz 1996). Building a nation was directly related to the creation of a civilization and, considering that civilization was defined in terms of racial groups, it was necessary to "fix" the Brazilian "racial problem." Brazilian scholars, therefore, argued they could whiten the country through miscegenation, resulting in the elimination of the Indigenous and, primarily, the Black influence (Consorte 1999; Costa 2001; Schwarcz 1996). That is, white people would predominate through this mixture, cleaning the nation of Black blood.

Thus, the Brazilian state started to incentivize the migration of Europeans to Brazil by funding their transportation to South America. It is estimated that millions of Europeans arrived in Brazil during this period. Nevertheless, Brazilian elites were accused of contributing to the degeneration of the white race by creating a "mongrel" population (Munanga 1999; Paschel 2016). This accusation is related to the expansion of U.S. imperialism. The United States often racializes foreign countries they exploit. Through the advancement of this imperialism, Brazilian elites were being taken out of the "white" category and defined as mestizos/non-whites (see more in Nunes 2008). Thus, it was imperative for Brazilian elites to break with hegemonic theories on miscegenation and to combat U.S. imperial power, even though they did not want to break with the myth of white superiority. Some Brazilian white scholars, for example, elaborated statistical studies in which they projected that, by 2012, Brazil would become a white country (Silva and Paixão, 2014).

In the United States, Du Bois was also interested in criticizing hegemonic discourses about miscegenation, which promoted his alignment with Brazilian elites. Juliet Hooker (2017), who studied his writing and activism on this topic, argues that Du Bois was a strong opponent of anti-miscegenation laws. He did not promote interracial marriage. Yet he understood the connection between these laws and lynching: anti-miscegenation rules helped perpetuate the stereotype of Black men as sexual predators and violent animals trying to rape "innocent" white women. In addition, Hooker argues that, at the beginning of his career, "Du Bois rejected racial science's biological account of race and proposed an alternate definition based on cultural and historical factors" (2017, p. 126), using miscegenation to challenge biological definitions of race.

This is exemplified by the unpublished article by Du Bois called Miscegenation, written in 1936. In this article, Du Bois argued that miscegenation has existed since the beginning of humanity. He wrote: "Modern Italians, Frenchmen, Englishmen, and Germans are composites of the broken fragments of different racial groups or sub-groups. Interbreeding has broken up ancient races and interaction and imitation have created types with uniformities in manners, language and behavior" (1936, p. 3). Thus, there was not a biological pure race. In fact, Du Bois argued that race was an artificial concept, without a clear scientific definition. For example, while some people identified three (Black, yellow, white), others found 150 races. He also argued that people usually were divided into races according to their morphological/phenotypic features, and the variation among racial types was due to 
the environment, not to biology. Based on this, Du Bois claimed that Blacks were in lower conditions than whites not because of allegedly biological inferiority but due to environmental circumstances, such as unemployment. Therefore, Du Bois used miscegenation to redefine race and to advocate for better conditions for Black people.

Finally, Du Bois criticized the idea that miscegenation led to degeneration (and, thus, that it should be prohibited) by claiming that at least some amount of miscegenation and exchange between races was a precondition to development and progress. Quoting Lacerda and his study on Brazil, Du Bois argued the Brazilian case was one example of mixed-race people being musicians, intellectuals, lawyers, etc. Also, using statistics on racial distribution, Du Bois demonstrated a substantial percentage of mulattoes among the U.S. population and that they were not inferior to whites. According to him, "the number of outstanding Americans of mulatto blood is considerable, including as it does Frederick Douglass, Booker T. Washington, Henry O. Tenner, the artist, and Charles W. Chestnut, the writer" (1936, p. 12).

In 1930, the second generation of Brazilian scholars emerged. They were writing when the European migration to Brazil was declining. It was clear, at that time, that Brazil would not become a white country but a place with a vast proportion of Black people (a category that included mulattoes). In addition, biological conceptions of race were being abandoned internationally. In this context, Brazilian scholars put miscegenation in the center of Brazil's national identity-Blacks, Indigenous, and the Portuguese were exalted as the three groups who formed the Brazilian people, each one contributing with their cultures (Schwarcz 1993). ${ }^{15}$ Two important representatives of this generation were Arthur Ramos and Gilberto Freyre. Ramos was considered the primary authority on Black studies in Brazil before Gilberto Freyre. In 1934, he published O Negro Brasileiro, a book on the African culture in Brazil with particular attention to the practice of Afro-religions. In this book, Ramos argued that Brazil's "Negro problem" was not related to racial biological inferiority but psychological issues. ${ }^{16}$ Gilberto Freyre, as previously mentioned, also criticized biological explanations of racial difference but simultaneously argued that there was racial harmony in Brazil.

Their works influenced the Brazilian state and racial politics from 1930 to 1988. During this period, there were two authoritarian governments: the Vargas era (1930-1945) and the military dictatorship (1964-1985). In both moments, the government used the myth of racial democracy to "unify" the nation-that is, to promote the idea of a cohesive and homogeneous Brazil where the people, especially the mass of Black folks, did not need to "complain" about racial inequality. To promote this allegedly unity, miscegenation became the base of an apparently raceless nation and the mulatto became a national symbol. In other words, racial politics in Brazil switched from Black erasure to mulatto celebration. In addition, some elements of the African culture were incorporated into national symbols, although transformed in folklore, while Black cultural centers were simultaneously submitted to intense surveillance from the government (Alencastro 1985; Carneiro 2011; Consorte 1999; Nascimento 1978; Paschel 2016).

Du Bois was aware of this academic change in Brazil. In 1936, he contacted scholars in Latin America to invite them to write for the Encyclopedia of the Negro. This work would be four volumes gathering texts on the Negro in Africa and its diaspora from different scholars, representing an important advance for Pan-Africanism. In Brazil, Du Bois contacted Arthur Ramos, who accepted the invitation to be a part of the project. ${ }^{17}$ Ramos sent Du Bois a list of major events related to Black people in Brazil and Portugal and a list of Brazilians (of any race) who have influenced Black people's lives. ${ }^{18}$

Unfortunately, Du Bois could not get enough funding to conclude the project. Nevertheless, in 1940, he compiled a list of themes that could have been included in the Encyclopedia, as well as suggestions of names to write about these topics. ${ }^{19}$ The list began 
quoting Gilberto Freye's works as references to studies in Brazil. He conveyed that Freye would have been the Brazilian with the most significant number of articles in the Encyclopedia.

Therefore, the emergence of the second generation of scholarship on race in Brazil did not negatively alter the alignment between Du Bois and these Brazilian scholars. In fact, their alignment against hegemonic discourses on miscegenation became stronger. In Brazil, elites still needed to disrupt theories that defined mixed-race people as inferior to pure-race individuals to justify embracing miscegenation as the formation of the Brazilian identity. In the United States, the Jim Crow system was being strengthened based on racist theories that defended segregation. Consequently, Du Bois still considered it essential to criticize hegemonic discourses on miscegenation to prove that other racial politics were possible.

This alignment did not mean the absence of conflicts. While Brazil's government was trying to whiten the country, especially before the 1930s, some African Americans started an immigration wave to the South American country searching for a "racial paradise." Through the Brazilian American Colonization Syndicate (BACS), for example, a group of African Americans created a land development company to initiate the settlement process in Brazil (see more in Meade and Pirio, 1988). The presence of U.S. Black citizens in Brazil was undesirable to Brazilian elites since they would "blacken" the country. Thus, there were two opposing groups in motion: Brazilian elites were trying to prohibit the entrance of Black folks (as well as Jews and Chinese people), and African Americans were creating projects to "recolonize" Brazil. The Brazilian Constitution from 1891 prohibited the entrance of Africans and Asians into the country. The Constitution from 1934 reinforced these policies, establishing that the number of immigrants allowed in Brazil should be limited considering race and ethnicity (Paschel 2016; Pereira 2013). In the United States, Black groups responded to Brazilian advertisements for immigration programs (likely made to target U.S. white citizens). These programs offered land, medical care, and transportation. Therefore, they organized themselves to migrate, publishing in newspapers like The Crisis and Baltimore Afro-American ads incentivizing African Americans to buy land in Brazil (Alberto 2011; Nunes 2008; Seigel 2009).

As a result, the Brazilian government started to deny visas to African Americans. Consequently, Du Bois wrote to both the President of Brazil and the United States Embassy in Brazil. ${ }^{20}$ In both letters, he asked if the Brazilian government discriminated against U.S. Black citizens. Du Bois received an answer from the Embassy, which claimed that there was not a specific prohibition to the entrance of African Americans in Brazil. ${ }^{21}$ Nevertheless, the visas were subjected to administrative approval, and any alien could be refused based on public order and national interests. Besides, according to the letter, some African Americans had their entrance denied because they had created an advertisement to send people to Brazilian states for colonization. Du Bois concluded that the United States government intimidated the Brazilian government into refusing Black people. ${ }^{22}$ In other words, Du Bois believed the racist practices in Brazil were caused by the U.S. influence rather than by the Brazilian whitening project. Therefore, despite the conflicts, the alignment between Du Bois and the Brazilian elites continued.

\section{Afro-Brazilian Movements and Du Bois's Elitism}

Since prior to the abolition of slavery in Brazil in 1888, Afro-Brazilian groups and associations were fighting for full citizenship. Additionally, the Afro-Brazilian press and political mobilization flourished during the twentieth century (Domingues 2007; Francisco 2014; Pinto 2018; Silva 2007). Black Brazilian intellectuals and activists often contributed to the myth of racial democracy by claiming that Brazil was rooted in harmony between 
racial groups (Guimarães 2004, 2019). However, while scholars such as Gilberto Freyre reproduced this idea to argue that racism didn't exist in Brazil, Afro-Brazilians reported racial prejudice in the country.

Some Afro-Brazilians even declared that Black's people experience in Brazil was worse than in the United States. In 1933, for example, the Afro-Brazilian activist and journalist José Correia Leite wrote that "we don't lynch Negroes, but we do more than that and completely extinguish the Negro race, abandoning it to syphilis, to idleness. [...] The Americans lynch fifty Negroes a year. We kill the entire Brazilian Negro race" (Leite quoted in Seigel 2009, pp. 202-203). Afro-Brazilians mobilized the idea of a racial paradise as a strategy to demand inclusion-not as a form to deny racism in Brazil. In other words, they argued the prejudice they faced was anti-Brazil and anti-progress and, consequently, should be eliminated (Alberto 2011; Campos 2015; Reis 2017).

Additionally, Afro-Brazilians criticized African Americans who represented Brazil as a racial paradise. Returning to Abbott's travel to the South American country, Abbott gave speeches in Brazil arguing that racism did not exist there. The Black Brazilian press intensely criticized his arguments. Abilio Rodrigues, for example, wrote that the racial equality in Brazil defended by Abbott was a fantasy: In his words, "one sees in every walk of life that the Black requires three times the effort to achieve a better position. (...) at each step we bump up against the prejudice that (...) crushes the man of color. And we continue to be undermined by the illusion that the real democracy is Brazilian because it is based on the principles of human equality" (Rodrigues quoted in Nunes 2008, p. 130). Besides, Benedito Florêncio wrote that "Dr. Robert Abbott's conferences (...) do not hold to a rigorous analysis because they are empty" (Florêncio quoted in Reis 2017, p. 42, author's translation). He affirmed that the hate against Black people was not demonstrated in Brazil like it was in the United States, but that "arguing that racism did not exist in Brazil is the same thing as denying that Germany lost the First World War" (Florêncio quoted in Reis 2017, p. 42, author's translation).

Despite this intense Afro-Brazilian mobilization and production, Du Bois did not interact with Afro-Brazilian groups. Instead, he sought to engage with Brazilian white scholars. Why did Du Bois prioritize relationships with Brazilian white scholars and not Black Brazilian intellectuals and activists? Although the shared agenda between Du Bois and Brazilian elites related to miscegenation is one factor, the above question still needs to be answered.

Two hypotheses should be explored. The first is that Du Bois was not aware of AfroBrazilian mobilization. In relation to this issue, it is important to remember that the transnational exchanges between Afro-diasporic subjects are not symmetrical. Micol Seigel (2009), for example, has demonstrated that imperialism impacts the international exchange of information and products so that news from the Global North circulates in the Global South more often than the inverse. In relation to the Black press, she writes that "the social boundaries of the U.S. and Brazilian black presses did not allow their representatives to interact on a level footing. Global power imbalances in the news and entertainment industries, publishing, foreign language acquisition, and raw wealth structured even the press..." (2009, p. 183). Due to this asymmetrical relationship, news of Black cultural and political mobilization in the United States would arrive more easily in Brazil than viceversa.

However, it is improbable that Du Bois was not aware of the Afro-Brazilian mobilization. When Arthur Ramos sent Du Bois a list of major events related to the Black people in Brazil and Portugal, he mentioned Afro-Brazilian intellectuals and groups, such as the Frente Negra Brasileira (FNB (Brazilian Black Front)) — a national Afro-Brazilian organization created in 1930. Besides, Petrônio Domingues (2013) has demonstrated that the FNB was widely known by the Black public in the United States and has even been pictured 
in some U.S. Black newspapers as "the most powerful organization from South America" (p. 156, author's translation).

Thus, a second hypothesis about why Du Bois prioritized the dialogue with Brazilian white academics should be explored. This hypothesis points to the inequalities that limited Afro-Brazilian possibilities to engage in transnational information exchanges and to Du Bois's elitism. Flávio Thales Ribeiro Francisco (2010), in his research about the Afrodiasporic dialogue with a focus on Brazil and the United States during the early twentieth century, argues there were two spheres in which this dialogue occurred. Academic relations characterized the first one. The second sphere was represented by the Black newspapers and the journalistic activity of Black activists. Afro-Brazilians rarely could participate in the first sphere. In Brazil, Black people, even those with better economic conditions, were excluded from schools and universities (see more in Machado, 2009; Nascimento, 1978). Therefore, Afro-Brazilians faced obstacles to participating in the academic sphere. However, Francisco argues that they participated in the Black press's transnational dialogue, which was more open to popular groups and individuals.

Although Du Bois was the editor of The Crisis for many years, he prioritized the academic sphere over the journalist/popular one while engaging with Brazil. To understand why this occurred, we need to consider his elitist perspective. It is well known that Du Bois had a strong elitist vein at the beginning of his career. ${ }^{23}$ This vein is demonstrated in one of his most known texts: the Talented Tenth (1903). In this text, Du Bois claimed that a Black elite should be developed through higher education, and this educated elite should lead the masses to progress. Therefore, he differentiated between the Black masses, composed of incapable and backward people, and the Black folk, a civilized and educated class that should be the leader of the masses (see more in Gooding-Williams, 2009).

Taking this into account, we can suppose Du Bois would prefer to engage with formally educated men and recognized scholars, prioritizing the academic sphere. Considering that Black Brazilians were excluded from educational spaces and that Brazilian academics were mainly white, he got closer to white Brazilian scholars than Afro-Brazilian intellectuals and activists. In other words, Du Bois likely prioritized the relationship with Brazilian white scholars because he identified himself as a member of the "academic elite," a group from which Afro-Brazilians were excluded.

\section{Towards a Conclusion}

In this article, I have explored Du Bois's contributions toward promoting the myth of racial democracy in Brazil up until about 1940. In addition, I discussed the reasons why he engaged with such a misleading assumption. During this period, Du Bois and other African Americans upheld an image of Brazil as a racial paradise in order to challenge the racial politics of the United States. Moreover, Du Bois aligned himself with Brazilian elites in defense of miscegenation, and Du Bois's elitism precluded his dialogue with AfroBrazilians. However, it is undeniable that Du Bois's intentions were related to Black liberation. Thus, in conclusion, I explore what we can learn from this experience to build an Afro-diasporic liberation project.

As one of the main figures of Pan-Africanism, Du Bois believed that Black people shared history and destiny due to slavery (Du Bois 1915, 1947, [1897] 2014). For him, the color line was a global problem, and Black people (and other people of color) only could be free when the myth of white superiority was defeated across the world. Du Bois also believed that Black international solidarity and cooperation were natural. For him, Black people shared a common identity based on their oppression and, consequently, a brotherhood among those of 'Negro blood' could be easily achieved (see more in Valdez 2019). 
In the past decades, many scholars have demonstrated that Black diasporic solidarity is not naturally developed (Edwards 2001; Lao-Montes 2007; Patterson and Kelley, 2000). The colonial and capitalist expansion was not uniform in time and space, creating connected but different systems across national boundaries. Consequently, Black experiences are different across time and space, and the links that tie the diaspora are not inevitable but rather are historically constituted. Based on this, scholars have also argued that global asymmetries among Black populations impact diasporic solidarity (Campt and Thomas, 2008; Kelley 2000). For example, Black people's position in global capitalism allows some Black folks to have more access to circulating across national borders than others, which creates asymmetries among Black populations that can challenge understanding and diasporic solidarity.

Du Bois's relationship with Brazil exemplifies the importance of considering these asymmetries. As earlier mentioned, African Americans and Afro-Brazilians do not interact in the transnational dialogue from equal positions. Imperialist countries use economic conditions (such as control over entertainment industries and publishing companies) to impose their agendas in other places. Due to this global inequality, African Americans have more access to platforms by which to divulge their experiences across the world than AfroBrazilians. Besides, while African Americans such as Robert Abbot could travel to Brazil and disseminate his experiences, Afro-Brazilians lacked economic and social capital to travel to the United States in the early twentieth century. Indeed, traveling abroad was an opportunity accessible almost exclusively to Brazilian elites. Unlike Afro-Brazilians, Brazilian white scholars such as Gilberto Freyre and Arthur Ramos traveled to the United States to share their studies. Yet, even these scholars faced challenges to traveling abroad due to global inequalities (Guimarães 2008, 2019; Oliveira 2019).

In this context, news about African Americans' experiences circulated more than information about Afro-Brazilians' situation (besides, this information was often mediated by Brazilian white scholars). As previously discussed, this did not preclude Du Bois from being aware of Afro-Brazilian mobilization. Yet, likely influenced by the inequalities in global information exchange, Du Bois analyzed Brazil based on his own experience and political agenda. He portrayed Brazil as a racial paradise to promote different racial politics in the United States. To do that, Du Bois overlooked variances in African American and Afro-Brazilian experiences, transforming African Americans' experience into a standard measure to define anti-Black racism. To be more specific, the fight against segregation marked his experience. In Brazil, on the other hand, there was no segregation. This does not mean that racism did not exist, only that it was performed differently. However, Du Bois interpreted this as overcoming the color line and, consequently, defined Brazil as a racial paradise that could be used to oppose the U.S. government's racial politics.

In addition, people's position in global capitalism impacts who is considered white, affecting Afro-diasporic dialogue and solidarity. As earlier discussed, U.S. elites racialize the population of the countries that they dominate (Nunes 2008). In relation to Brazil, this occurred through the competition between two racial projects. While Brazilian elites sought to whiten the population through miscegenation, the U.S. elites promoted segregation and anti-miscegenation politics. As the U.S. imperial attitude extended into Brazil, the Brazilian racial project was rejected by U.S. forces. Brazilian elites were classified as mestizos/non-whites and accused of creating a mongrel population through miscegenation.

This facilitated the alignment between Du Bois and Brazilian elites. The former fought against anti-Black violence in the United States, criticizing segregationist laws, biological definitions of race, and anti-miscegenation discourses. The latter fought against U.S. imperialism and its racial components. However, Brazilian elites did not intend to end anti-Blackness but ensure their international status as white people. In other words, Afro-Brazilian liberation was not their agenda. Therefore, Du Bois and Brazilian elites had 
a convergence of interests due to their position in global capitalism: both were fighting against U.S. imperial rule and its anti-miscegenation discourse. However, Afro-Brazilians were fighting against these politics, U.S. imperialism, and Brazilian elites.

Therefore, Du Bois's Pan-African agenda concerning Brazil was obscured by global inequalities and the imbalance of power in the Americas. Consequently, it exemplifies the importance of considering asymmetries among Black people and how they can challenge Afro-diasporic solidarity. Finally, Du Bois's relationship with Brazil teaches us a valuable lesson concerning transnational solidarity. Black transnationalism is not automatic. We must build it, and, for that, we need to dedicate time, work, effort, sweat - taking the differences between Black communities seriously.

\section{Acknowledgements}

This research was supported by the W. E. B. Du Bois Center at the University of Massachusetts Amherst. I want to thank Prof. Lao-Montes, Prof. Battle-Baptiste, Prof. de Leon, Prof. Bracey, and the members of the 2020 UMass sociology graduate program writing seminar for your comments.

\section{Notes}

${ }^{1}$ In this article, Black is capitalized when the term refers to a racial or ethnic group. However, white is not capitalized. This is an intentional movement to highlight and recognize Black struggle in the Americas, as well as the system of power that marginalizes Black folks.

2 Du Bois changed his opinion about Brazil after 1940. Instead of picturing the place as a racial paradise, he started to denounce the racism in that country. This change is related to Du Bois's increasing connection to Marxism and Brazilian communists. In addition, it is connected to the increased number of African Americans who traveled to Brazil after 1940, such as Franklin Frazier, Irene Diggs, Lorenzo Turner, Katherine Durham, and George Schuyler. Du Bois's relationship with Brazil after 1940 will be explored in a later article.

3 See Sansone (2011), Pereira (2013), and Francisco (2014) for other African Americans engaging with the myth of racial democracy and the reasons for such engagement.

${ }^{4}$ For this work, I searched primary sources from the W. E. B. Du Bois Papers at the University of Massachusetts at Amherst. As mentioned, I analyzed more than 100 documents in the archive related to Brazil, among letters exchanged about the South American country (with Brazilians or others) and publications. In addition, I analyzed articles in The Crisis (the NAACP newspaper, where Du Bois served as editor), and secondary sources on the Black press in the United States and in Brazil. For future studies, material on Du Bois is available for consultation in the archives at both Harvard and Fisk University.

5 Miscegenation, with its racist connotation, is exactly the term used by Freyre. As it will be explained later, Brazilian elites never intended to build a multiracial country. On the contrary, they wanted to eliminate Black people through miscegenation.

6 The author does not use the term "racial democracy" in the two books mentioned. He used the term after 1950.

7 Lacerda also wrote about his meeting with Du Bois. He argued that Du Bois was an intelligent mulatto and that he proved that his race could be improved with academic education. See Rocha (2010).

${ }^{8}$ Letter from Roy Nash to W. E. B. Du Bois, January 8, 1923. W. E. B. Du Bois Papers (MS 312). Special Collections and University Archives, University of Massachusetts Amherst Libraries.

9 Letter from W. E. B. Du Bois to Roy Nash, January 17, 1923. W. E. B. Du Bois Papers (MS 312). Special Collections and University Archives, University of Massachusetts Amherst Libraries.

${ }^{10}$ Letter from W. E. B. Du Bois to Roy Nash, May 9, 1923. W. E. B. Du Bois Papers (MS 312). Special Collections and University Archives, University of Massachusetts Amherst Libraries.

11 Letter from Mrs. T. Ross Farmer to The Crisis, January 22, 1927. W. E. B. Du Bois Papers (MS 312). Special Collections and University Archives, University of Massachusetts Amherst Libraries. See also Letter from W. E. B. Du Bois to Mrs. T. Ross Farmer, March 9, 1927. W. E. B. Du Bois Papers (MS 312). Special Collections and University Archives, University of Massachusetts Amherst Libraries.

12 Farmer affirmed she would like to write an article about it for The Crisis. Unfortunately, the article was not found. Nevertheless, the exchange of letters between her and Du Bois is an example that he had access to concerning reports on Brazil.

13 Letter from Owen Johnson to W. E. B. Du Bois, November 18, 1927. W. E. B. Du Bois Papers (MS 312). Special Collections and University Archives, University of Massachusetts Amherst Libraries. 
14 By generations I do not mean a difference in age, but a cohort difference. Many of the scholars of the first generation also belonged to the second one. Nevertheless, there was a clear demarcation in terms of academic production.

15 The roots of the discourse that Brazil was formed by white, Black, and Indigenous people were created in 1844. See more in Schwarcz (1993).

16 Arthur Ramos started his book talking about Black people from the United States and the color line, as well as mentioning Du Bois. He argued that "the color line is everything that divide two races in a big and hated way" (1934, p. 8, author's translation) and Black U.S. citizens were reacting to the increase of lynching through music, dance, and organizations like the NAACP, "that are led by great Black writers like Du Bois, Calverton, Brawley, Walter White, etc.” (1934, p. 11, author's translation).

17 The contact was made by Rayford W. Logan, a Black scholar and activist, in Du Bois's name, who was travelling. See in: Letter from Rayford W. Logan to Richard L. Pattee, October 10, 1936. W. E. B. Du Bois Papers (MS 312). Special Collections and University Archives, University of Massachusetts Amherst Libraries.

18 Ramos, Arthur. List of major events to do with the Negro in Brazil and Portugal, March 16, 1937. W. E. B. Du Bois Papers (MS 312). Special Collections and University Archives, University of Massachusetts Amherst Libraries. Ramos, Arthur. List of Brazilians of any race who have influenced Negro life, March 16, 1937. W. E. B. Du Bois Papers (MS 312). Special Collections and University Archives, University of Massachusetts Amherst Libraries.

19 Suggested topics with reference to the Negro in Brazil, ca. 1940. W. E. B. Du Bois Papers (MS 312). Special Collections and University Archives, University of Massachusetts Amherst Libraries.

${ }^{20}$ Letter from W. E. B. Du Bois to the President of the Republic of Brazil, November 16, 1926. W. E. B. Du Bois Papers (MS 312). Special Collections and University Archives, University of Massachusetts Amherst Libraries. Letter from W. E. B. Du Bois to the United States Embassy, Brazil, January 21, 1927. W. E. B. Du Bois Papers (MS 312). Special Collections and University Archives, University of Massachusetts Amherst Libraries.

21 Letter from United States Embassy, Brazil to W. E. B. Du Bois, February 10, 1927. W. E. B. Du Bois Papers (MS 312). Special Collections and University Archives, University of Massachusetts Amherst Libraries.

22 See Letter from M. Denton Jr. to the NAACP, October 29, 192. W. E. B. Du Bois Papers (MS 312). Special Collections and University Archives, University of Massachusetts Amherst Libraries. Letter from W. E. B. Du Bois to M. Denton Jr., November 7, 1928. W. E. B. Du Bois Papers (MS 312). Special Collections and University Archives, University of Massachusetts Amherst Libraries.

23 This changes as he approaches Marxism and communist movements. See Du Bois ([1952]2014).

\section{References}

Alberto, Paulina (2011). Terms of Inclusion: Black Intellectuals in Twentieth-Century Brazil. Chapel Hill, NC: University of North Carolina Press.

Alencastro,Luiz Felipe de (1985). Geopolítica da Mestiçagem. Novos Estudos, 11: 49-64.

Campos, Luiz Augusto (2015). "O Negro é Povo no Brasil”: Afirmação da Negritude e Democracia Racial em Alberto Guerreiro Ramos (1948-1955). Caderno CRH, 28: 91-110.

Campt, Tina, and Deborah A. Thomas (2008). Gendering Diaspora: Transnational Feminism, Diaspora and its Hegemonies. Feminist Review, 90(10): 1-8.

Carneiro, Sueli (2011). Racismo, Sexismo e Desigualdade no Brasil. São Paulo, Brazil: Selo Negro.

Cerqueira, Daniel, Samira Bueno, Paloma Alves, Renato Lima, Enid Silva, Helder Ferreira, Amanda Pimentel, Betina Barros, David Marques, Dannis Pacheco, Gabriel Lins, Igor Lino, Isabela Sobral, Isabel Figueiredo, Juliana Martins, Karolina Armstrong, and Taís Figueiredo (2020). Atlas da Violência. Brasília, Brazil: IPEA.

Consorte, Josidelth Gomes (1999). A Mestiçagem no Brasil: Armadilhas e Impasses. Revista Margem, 10: $107-117$.

Costa, Sérgio (2001). A Mestiçagem e seus Contrários: Etnicidade e Nacionalidade no Brasil Contemporâneo. Tempo Social, 13(1): 143-158.

Domingues, Petrônio (2005). O Mito da Democracia Racial e a Mestiçagem no Brasil (1889-1930). Diálogos Latinoamericanos, 10: 117-131.

Domingues, Petrônio (2007). Movimento Negro Brasileiro: Alguns Apontamentos Históricos. Tempo, 12(23): $100-122$.

Domingues, Petrônio (2013). Como se Fosse Bumerangue: Frente Negra Brasileira no Circuito Transatlântico. Revista Brasileira de Ciências Sociais, 28(81): 155-170.

Du Bois, William Edward Burghardt (1903). The Talented Tenth. New York: James Pott and Company.

Du Bois, William Edward Burghardt (1914). Brazil. The Crisis, April, 286-287.

Du Bois, William Edward Burghardt (1915). The Negro. New York: Henry Holt and Company.

Du Bois, William Edward Burghardt (1916). Baltimore Afro-American, January 15. 
Du Bois, William Edward Burghardt (1936). Miscegenation. Unpublished Manuscript, Special Collections and University Archives, University of Massachusetts Amherst Libraries.

Du Bois, William Edward Burghardt (1947). The Pan-African Movement. In George Padmore (Ed.), Colonial and Coloured Unity: A Programme of Action/ History of the Pan-African Congress, pp. 13-26. London: The Hammersmith Bookshop LTD.

Du Bois, William Edward Burghardt ([1897] 2014). The Conservation of Races. In Nahum Dimitri Chandler (Ed.), The Problem of the Color Line at the Turn of the Twentieth Century, pp. 51-66. New York: Fordham University Press.

Du Bois, William Edward Burghardt ([1952] 2014). In Battle for Peace: The Story of My 83rd Birthday. London: Oxford University Press.

Edwards, Brent Hayes (2001). The Uses of Diaspora. Social Text, 19(1): 45-73.

Escóssia, Fernanda da (2016). A Cada 23 Minutos, Um Jovem Negro é Assassinado no Brasil, diz CPI. BBC News, June 6. https://www.bbc.com/portuguese/brasil-36461295 (accessed July 31, 2021).

Francisco, Flávio Thales Ribeiro (2010). Fronteiras em Definição: Identidades Negras e Imagens dos Estados Unidos e da África no Jornal "O Clarim da Alvorada” (1924-1932). Masters Thesis, Department of History, University of São Paulo.

Francisco, Flávio Thales Ribeiro (2014). O Novo Negro em Perspectiva Transnacional. Representações AfroAmericanas sobre o Brasil e a França no jornal Chicago Defender (1916-1940). PhD Dissertation, Department of History, University of São Paulo.

Freyre, Gilberto (2003 [1933]). Casa-Grande e Senzala: A Formação da Família Brasileira sob o Regime da Economia Patriarcal. São Paulo, Brazil: Editora Global.

Freyre, Gilberto (2013 [1936]). Sobrados e Mucambos: Decadência do Patriarcado Rural e Desenvovlimento do Urbano. São Paulo, Brazil: Editora Global.

Gonzalez, Lélia (1984). Racismo e Sexismo na Cultura Brasileira. Revista Ciências Sociais Hoje, 2(1): 223-244.

Gooding-Williams, Robert (2009). In the Shadow of Du Bois: Afro-Modern Political Thought in America. Cambridge, MA: Harvard University Press. doi:10.2307/j.ctvjhzqcr.

Guimarães, Antonio (2004). Intelectuais Negros e Formas de Integração Nacional. Estudos Avançados, 18(50): 271-284.

Guimarães, Antonio (2008). Africanism and Racial Democracy: The Correspondence Between Herskovits and Arthur Ramos (1935-1949). ELAL: Estudios Interdisciplinarios de America Latina y el Caribe, 19(1): 53-79.

Guimarães, Antonio (2019). A Democracia Racial Revisitada. Afro-Asia, 60: 9-44.

Hanchard, Michael (1994). Orpheus and Power: The Movimento Negro of Rio de Faneiro and São Paulo, Brazil, 19451988. Princeton, NJ: Princeton University Press.

Hellwig, David J. (1990). Racial Paradise or Run-Around?: Afro-North American Views of Race Relations in Brazil. American Studies, 31(2): 43-60.

Hooker, Juliet (2017). Theorizing Race in the Americas: Douglass, Sarmineto, Du Bois, and Vasconcelos. London: Oxford Scholarship.

IBGE (Brazilian Institute of Geography and Statistics) (2019). Desigualdes Sociais por Cor ou Raça no Brasil. Estudos e Pesquisas: Informação Demográfica e Socioecônomica, 41:1-12.

IBGE (2020). Características Gerais dos Domícilios e dos Moradores 2019. Pesquisa Nacional por Amostra de Domicilios Contínua. https://biblioteca.ibge.gov.br/visualizacao/livros/liv101707_informativo.pdf (acessed July 31, 2021).

Kelley, Robin (2000). How the West Was One: On the Uses and Limitations of Diaspora. The Black Scholar, 30(3/4): 31-35.

Lacerda, João (1911). The Metis, or Half-Breeds, of Brazil. In G. Spiller (Ed.) Papers on Inter-Racial Problems Communicated to the First Universal Races Congress Held at the University of London, Fuly 26-29, 1911, pp. 377-382. London: P. S. King \& Son.

Lao-Montes, Agustin (2007). Decolonial Moves: Trans-locating African Diaspora Spaces. Cultural Studies, 21(2): 309-338.

Machado, Carlos Eduardo Dias (2009). População Negra e Escolarização na Cidade de São Paulo nas Décadas de 1920 e 1930. PhD Dissertation, Department of History, University of São Paulo.

Meade, Teresa, and Gregory Alonso Pirio (1988). In Search of the Afro-American "Eldorado": Attempts by North American Blacks to Enter Brazil in the 1920s. Luso-Brazilian Review, 25(1): 85-110.

Munanga, Kabengele (1999). Rediscutindo a Mestiçagem no Brasil: Identidade Nacional versus Identidade Negra. Petrópolis, Rio de Janeiro: Editora Vozes.

Nascimento, Abdias (1978). O Genocídio do Negro Nrasileiro: Processo de um Racismo Mascarado. Rio de Janeiro, Brazil: Editora Paz e Terra. 
Nunes, Zita (2008). Cannibal Democracy: Race and Representation in the Literature of the Americas. Minneapolis, MN: University of Minnesota Press.

Oliveira, Amurabi (2019). Afro-Brazilian Studies in the 1930s: Intellectual Networks Between Brazil and the U.S. Brasiliana: Fournal for Brazilian Studies, 8(1-2): 32-49.

Paschel, Tiana S. (2016). Becoming Black Political Subjects. Princeton, NJ: Princeton University Press.

Patterson, Tiffany, and Robin Kelley (2000). Unfinished Migrations: Reflections on the African Diaspora and the Making of the Modern World. African Studies Review, 43(1): 11-45.

Pereira, Amilcar Araújo (2013). O Mundo Negro: Relações Raciais e a Constituição do Movimento Negro Compoterâneo no Brasil. Rio de Janeiro, Brazil: Pallas Editora.

Pinto, Ana Flávia Magalhães (2018). Escritos de Liberdade: Literatos Negros, Racismo e Cidadania no Brasil Oitocentista. Campinas, Brazil: Editora Unicamp.

Ramos, Arthur (1934). O Negro Brasileiro. São Paulo, Brazil: Civilização brasileira.

Reis, Ruan Levy Andrade (2017). Letras de Fogo, Barreiras de Lenha: a Produção Intelectual Negra Paulista em Movimento (1915-1931). PhD Dissertation, Department of History, University of São Paulo.

Rocha, Vera da Silva (2010). Mesticagem na Bahia: Um Estudo sobre a Construção da Identidade na Cidade de Salvador. Master's Theses, Multidisciplinary Graduate Program in Ethnic and African Studies, Federal University of Bahia.

Roosevelt, Theodore (1914). Brazil and the Negro. The Outlook, February 21, 409-411.

Sansone, Livio (2011). USA and Brazil in Gantois: Power and the Transnational Origin of Afro-Brazilian Studies. Vibrant: Virtual Brazilian Anthropology, 8: 536-567

Schwarcz, Lilia K. Mortiz (1993). O Espetáculo das Raças: Cientistas, Instituições e a Questão Racial no Brasil do século XIX. São Paulo, Brazil: Editora Companhia das Letras.

Schwarcz, Lilia K. Mortiz (1996). Usos e Abusos da Mestiçagem e da Raça no Brasil: Uma História das Teorias Racias em Finais do Século XIX. Afro-Ásia, 18: 77-101.

Seigel, Micol (2009). Uneven Encounters: Making Race and Nation in Brazil and the United States. Durham, NC: Duke University Press.

Silva, Graziella M., and Marcelo Paixão (2014). Mixed and Unequal: New Perspectives on Brazilian Ethnoracial Relations. In Edward Telles (Ed.), Pigmentocracies: Ethnicity, Race, and Color in Latin America., pp. 172-217. Chapel Hill, NC: UNC Press Books.

Silva, Luiz (2007). E Disse o Velho Militante José Correira Leite. São Paulo, Brazil: Noovha America.

Souza, Neusa Santos ([1983] 1990). Tornar-se Negro. Rio de Janeiro, Brazil: Edições Graal.

Telles, Edward (2014). Pigmentocracies: Ethnicity, Race, and Color in Latin America. Chapel Hill, NC: UNC Press Books.

Valdez, Inés (2019). Transnational Cosmopolitanism: Kant, Du Bois, and fustice as a Political Craft. New York: Cambridge University Press.

Waiselfisz, Julio Jacobo (2015). Mapa da Violência 2015: Homícidios de Mulheres no Brasil. Brasília, Brazil: FLACSO.

W. E. B. Du Bois. Papers Special Collections and University Archives, University of Massachusetts Amherst Libraries.

Juliana Góes is a PhD candidate in sociology at University of Massachusetts at Amherst where she was a Fellow at the W. E. B. Du Bois Center (2018). Currently, Góes is working on a book manuscript called Du Bois on Latin America and the Caribbean: Trans-American Pan-Africanism and Global Sociology (co-authored with Agustin LaoMontes and Jorge Vasquez). Additionally, she studies the connection between Black movements in Latin America, decolonial praxis, urban politics. Her dissertation title is Decolonizing Cities: Afro-Descendant Movements and Territories of Life in Brazil. Her articles have appeared in the LASA Forum, Revista Politica e Sociedade, Revista Estudos Feministas, Caderno Espaço Feminino. Góes also has collaborated with Black urban settlements, sex workers organizations, and anti-prison movements in Brazil.

Cite this article: Góes, Juliana (2022). Du Bois and Brazil: Reflections on Black Transnationalism and African Diaspora. Du Bois Review: Social Science Research on Race, 19: 293-308. https://doi.org/10.1017/S1742058X2100045X 